\title{
Plantago ovata seeds as dietary fibre supplement: physiological and metabolic effects in rats
}

\author{
BY ELKE LENG-PESCHLOW \\ Department of Pharmacology, Madaus AG, Ostmerheimer Str. 198, D-5000 Köln 91, Germany
}

(Received 21 March 1990 - Accepted 19 December 1990)

\begin{abstract}
In rats, the effects of a 4-week supplementation of a fibre-free elemental diet with 100 or $200 \mathrm{~g}$ Plantago ovata seeds/kg was compared with that of the husks and wheat bran. The seeds increased faecal fresh weight up to $100 \%$, faecal dry weight up to $50 \%$ and faecal water content up to $50 \%$. The husks, at the high concentration only, were more effective and wheat bran less effective. Length and weight of the small intestine were not greatly affected by the seeds, but both variables increased significantly in the large intestine. The husks had more pronounced effects, especially in the small intestine, and wheat bran almost no effect. Faecal bacterial mass as estimated from the 2,6-diaminopimelic acid output was increased to the greatest extent by the seed-containing diet and by the high concentration of husks, but to a lesser extent by wheat bran. Faecal and caecal protein content was enhanced by the seeds and wheat bran, but to a lesser extent by the husks. Total acetate in caecal contents or faeces was highest on the seeds and husks diet and not elevated by wheat bran. Total faecal bile acid excretion was stimulated and $\beta$-glucuronidase (EC 3.2.1.31) activity reduced by both Plantago ovata preparations, but not by wheat bran. Mucosal digestive enzyme activities were inhibited to different degrees by all dietary fibres in the jejunum, and sometimes activated in the ileum. These results suggest that Plantago ovata seeds are a partly-fermentable dietary fibre supplement which increases stool bulk; metabolic and mucosa-protective effects are also probable.
\end{abstract}

Plantago ovata: Dietary fibre supplement

Dietary fibres from natural or semi-synthetic sources have gained increasing attention as a supplement to the normal Western diet, which is poor in bulking substances, and as a prophylactic or therapeutic treatment of large bowel disorders (Dreher, 1987). Plantago ovata husks, often referred to as ispaghula (husks) or as psyllium (which is a misleading term as nearly all the commercially-available drug derives from Plantago ovata Forsk. and not from Plantago psyllium L.) and wheat bran are widely used and well-investigated examples. Both compounds increase stool weight (Stevens et al. 1988), but have rather opposite physicochemical properties regarding solubility and water-binding capacity (Eastwood et al. 1983; Van Soest, 1984; Englyst et al. 1989).

Another fibre source, less well known, is Plantago ovata seeds. In contrast to the husks which consist only of the hulls of the seeds, the seed preparation includes the kernel together with the hulls. The water-holding capacity of the seeds is intermediate between that of the husks and wheat bran (Sosulski \& Cadden, 1982; Struthers, 1986; LengPeschlow, 1990). Clinical studies with a Plantago ovata seed preparation indicate that this compound increases stool weight and reduces intestinal transit time in healthy volunteers (Heckers \& Zielinsky, 1984) and augments stool frequency, stool mass, and water content in constipated patients (Sölter \& Lorenz 1983; Marlett et al. 1987). Symptoms in irritable bowel patients are ameliorated and consumption of spasmolytics reduced (Ligny, 1988). There is no information about this fibre derived from animal studies. 
Table 1. Fibre content of the experimental fibre supplements

(Determined according to the Association of Official Analytical Chemists (Prosky et al. 1985))

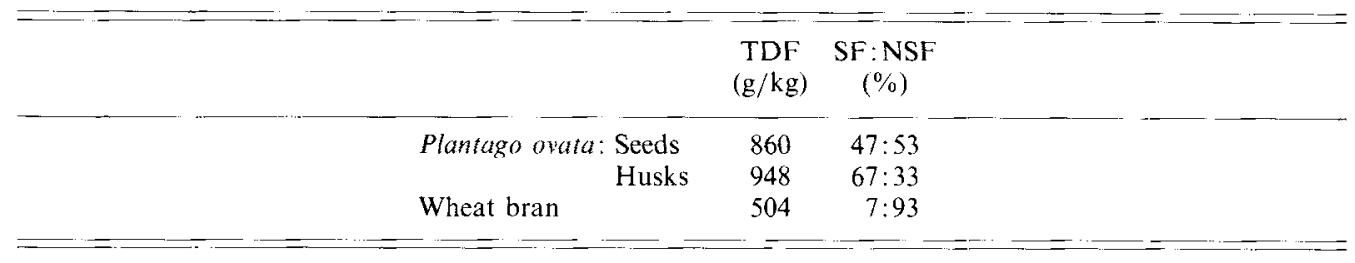

TDF, total dietary fibre; SF, soluble fibre; NSF, insoluble fibre.

The present experiments in rats were performed to characterize the properties of Plantago ovata seeds as a dietary fibre supplement. The husks and wheat bran were used for comparison. A feeding period of 4 weeks was chosen as it has been shown that this timeperiod is sufficient for most variables to adapt to the diet change (Walter et al. 1986).

\section{EX PERIMENTA L}

Animals and diets

Seventy female adult Wistar rats supplied by Mus Rattus (Brunnthal, Germany) were caged in pairs under standardized experimental conditions (room temperature $22 \pm 2^{\circ}$, relative air humidity $43 \pm 2 \%$, light-dark cycle $12: 12 \mathrm{~h}$ ). Water and food were freely available. All animals were allocated randomly into seven groups and adapted for $14 \mathrm{~d}$ to a low-residue, nutritionally-complete, pelleted elemental diet (ssniff-Spezialitäten, Soest, Germany) containing (g/kg): casein 145 , starch 415 , sucrose 150 , glucose 150 , soya-bean oil 20 , vitamin mixture 10 (retinol $4 \mathrm{mg}$, thiamin mononitrate $20 \mathrm{mg}$, riboflavin $20 \mathrm{mg}$, pyridoxine hydrochloride $20 \mathrm{mg}$, cyanocobalamin $30 \mu \mathrm{g}$, L-ascorbic acid $15 \mathrm{mg}$, cholecalciferol $15 \mathrm{mg}, \alpha$-tocopherol acetate $140 \mathrm{mg}$, biotin $150 \mu \mathrm{g}$, menadione $10 \mathrm{mg}$, calcium-D-pantothenate $60 \mathrm{mg}$, nicotinamide $50 \mathrm{mg}$, folic acid $10 \mathrm{mg}$, myo-inositol $80 \mathrm{mg}$, p-aminobenzoic acid $80 \mathrm{mg}$, choline chloride $1,000 \mathrm{mg}$, rutin $50 \mathrm{mg}$, orotic acid $60 \mathrm{mg}$, DL-methionine $1,000 \mathrm{mg})$ and mineral salt mixture $60\left(\mathrm{CaCO}_{3} 18 \mathrm{~g}, \mathrm{Ca}_{5}\left(\mathrm{PO}_{4}\right)_{3}(\mathrm{OH}) 9 \cdot 75 \mathrm{~g}\right.$, $\mathrm{CoCl}_{2} 0.5 \mathrm{mg}, \mathrm{CuSO}_{4} .5 \mathrm{H}_{2} \mathrm{O} 25 \mathrm{mg}$, ferrous fumarate $500 \mathrm{mg}, \mathrm{K}_{2} \mathrm{HPO}_{4} 11 \mathrm{~g}, \mathrm{KI} 0.5 \mathrm{mg}$, $\mathrm{MgSO}_{4} .7 \mathrm{H}_{2} \mathrm{O} 5.5 \mathrm{~g}, \mathrm{MnSO}_{4} . \mathrm{H}_{2} \mathrm{O} 450 \mathrm{mg}, \mathrm{NaCl} 7.6 \mathrm{~g}, \mathrm{NaF} 9.5 \mathrm{mg}, \mathrm{Na}_{2} \mathrm{HPO}_{4} 7 \cdot 1 \mathrm{~g}$, $\left.\mathrm{Na}_{2} \mathrm{MoO}_{4} .2 \mathrm{H}_{2} \mathrm{O} 0.5 \mathrm{mg}, \mathrm{NH}_{4} \mathrm{AL}\left(\mathrm{SO}_{4}\right)_{2} 19 \mathrm{mg}, \mathrm{ZnCO}_{3} 45 \mathrm{mg}\right)$.

After the adaptation period, finely powdered Plantago ovata seeds, including approximately the natural amount of husks, whole Plantago ovata husks (both supplied by Madaus AG, Cologne, Germany) or coarse wheat bran (Milupa AG, Friedrichsdorf, Germany) were added to the elemental diet ( 100 or $200 \mathrm{~g} / \mathrm{kg}$ ). The seventh group (controls) received the elemental diet for the whole experimental period. Each diet was given in a pelleted form to groups of ten rats for 4 weeks. The total fibre content of the supplements was analysed according to the Association of Official Analytical Chemists method (Prosky et al. 1985) and the insoluble and soluble components after separation by filtration (Rabe et al. 1988). The fibre compositions are given in Table 1 and the particle sizes of each supplement (determined by sieve analysis) in Table 2 .

\section{Experimental procedure}

Body-weight, food consumption and stool output were measured once weekly. For this purpose, the rats were placed individually in wide-gridded cages for $24 \mathrm{~h}$. Stool collections were made at hourly intervals over $8 \mathrm{~h}$ during the day and in a single $16 \mathrm{~h}$ period during 
Table 2. Distribution (\%) of particle sizes of the dietary fibres

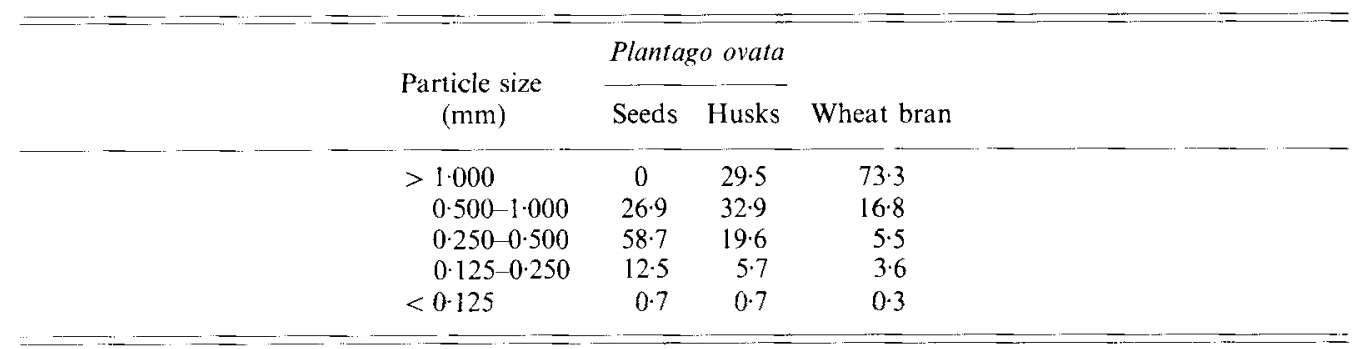

the night. Fresh and dry weights of the faeces were determined for the daytime collections, dry weight only for the night-time collections. Food consumption was simultaneously measured by reweighing the food residues after $24 \mathrm{~h}$ for each animal. The dried faeces of the 2 nd and 4 th week were frozen at $-60^{\circ}$ for further analyses (protein, acetate, total bile acids, and 2,6-diaminopimelic acid (DAPA)). $\beta$-Glucuronidase (EC 3.2.1.31) activity was determined weekly in a freshly collected faecal pellet.

At the end of week 4 , in the morning after the last stool collection period, rats were anaesthetized with ketamine + xylazine $((50+4) \mathrm{mg} / \mathrm{kg}$ body-weight in $4 \mathrm{ml}$ physiological saline ( $9 \mathrm{~g}$ sodium chloride/1) given intraperitoneally) and, after removal of the intestine, killed by an overdose of anaesthetic. The $\mathrm{pH}$ of the caecal contents was measured through a small incision in situ. The lengths of the small intestine and colon were determined. The whole small intestine, caecum, and colon were weighed immediately with and without contents, the tissues were dried at $60^{\circ}$ and reweighed. From the small intestine, three pieces of $100 \mathrm{~mm}$ in length (proximal, middle and distal part) were used for tissue weight determinations. Scrapings of the mucosa were immediately taken from two other pieces of $100 \mathrm{~mm}$ length (proximal jejunum, distal ileum). The mucosa was homogenized in ice-cold buffer (Farness \& Schneeman, 1982) and frozen at $-60^{\circ}$ until enzyme determinations.

A sample of fresh caecal contents was preserved in an ice bath for subsequent analysis of $\beta$-glucuronidase, the rest was dried and frozen at $-60^{\circ}$ for further determinations.

\section{Analyses}

$\beta$-Glucuronidase in faeces and caecal contents was determined according to Shiau \& Chang (1983), DAPA according to Czerkawski (1974), acetate by a commercially-available enzymic test kit (Boehringer Mannheim, Mannheim, Germany), total $3 \alpha$-hydroxy bile acids after extraction from faeces (Evrard \& Janssen, 1968) using an enzymic test kit (Merck, Darmstadt, Germany) and protein, after homogenization and extraction from faeces or caecal contents with $0.1 \mathrm{M}$-sodium hydroxide $\left(3 \mathrm{~h}, 50^{\circ}\right)$, in the supernatant fraction using a protein assay kit (Sigma, Deisenhofen, Germany).

Small intestinal mucosal enzymes (alkaline phosphatase EC 3.1.3.1. (AP), sucrase $E C$ 3.2.1.48, leucine aminopeptidase $E C$ 3.4.11.1 (LAP), $\alpha$-amylase $E C 3.2 .1 .1$ ) and mucosal protein were determined in the thawed homogenates using commercially-available test kits for protein (Sigma, Deisenhofen, Germany), AP (Hoffmann La Roche, Grenzach, Germany), LAP and $\alpha$-amylase (Boehringer, Mannheim, Germany). Sucrase was analysed according to Dahlqvist (1970) using a glucose test kit (Boehringer, Mannheim, Germany).

All results are given as means and standard deviations. Fibre-supplemented groups are compared with the fibre-free control by Student's $t$ test using a two-tailed evaluation. In the case of unequal variances, the Welch test was used. 
RESULTS

Body-weight and food intake

Food intake after the sudden change to the fibre-enriched diet was reduced to the greatest extent in the groups receiving the diet with Plantago ovata husks, to a lesser extent in the seed-diet groups and still less in the wheat-bran-diet groups compared with the fibre-free controls. After 4 weeks there were no significant differences compared with the control group, but there was a tendency to an increased consumption of the high-fibre-content diets compared with the corresponding diet with half the fibre content (Table 3).

Body-weight gain with the seed- or husk-containing diets was comparable with that of the fibre-free control diet. Both wheat-bran groups, but most markedly the high-fibre group, showed a smaller gain. The $200 \mathrm{~g}$ wheat bran $/ \mathrm{kg}$ group, however, had initially higher body-weights in spite of the randomization procedure. As food intake was similar to that of the other groups, the food conversion efficiency was lower in both wheat-bran groups (Table 3).

\section{Faecal excretion}

The faecal pellets of the fibre-free group were small and hard. Plantago ovata seeds and husks increased the size of the pellets and their number by up to $100 \%$. Although the pellets were well-formed in both groups, their consistency was soft and the interior, especially with the husk-diet group, was like gum. Wheat bran increased the number of faecal pellets by $20-50 \%$, but did not change their consistency.

There were some variations in faecal excretion during the 4 weeks but, principally, similar results were obtained for the same diet after 1 week or 4 weeks of treatment. Therefore, the results from all four sampling occasions for each dietary group were combined (Table 3).

Daily faecal dry weight significantly increased only with the $200 \mathrm{~g}$ husks $/ \mathrm{kg}$ diet, but there was the same tendency for the other fibre-rich diets compared with the fibre-free controls. Water content and fresh weight of the faeces was pronouncedly and dosedependently higher with both Plantago ovata diets but not with wheat bran. Daily fresh weights represent a rough estimation since they are based on the mean faecal water content of the day's collection periods, not available from all animals.

\section{Intestinal lengths and weights}

The length of the small intestine increased with the seed-containing diet by $48 \%$ and with the husk-containing diet by 13-24\% (Table 4). Wheat bran did not influence small intestinal length. In the colon, both Plantago ovata preparations induced a $10-20 \%$ increase in length, bran had an effect only in the high dose (10\% increase).

The total fresh weight of the small intestine was $3040 \%$ higher in rats fed on seeds and $85-150 \%$ higher in the husk-fed groups, whereas there was little or no change with wheat bran. Plantago ovata seeds increased caecal weight by $116-145 \%$, husks by $141-286 \%$ and bran by $13-29 \%$. The corresponding values for total colon weight were $47-110 \%$ for seeds, $90-202 \%$ for husks and $0-42 \%$ for wheat bran.

The amount of small intestinal contents estimated by total weight, total length and average tissue weight based on three segments was negligible in the fibre-free and lowwheat-bran groups and was less than $10 \%$ of the total fresh weight of the small intestine in the seed-fed and high-wheat-bran groups. The contents represented, however, approximately $30 \%$ of the total small intestinal wet weight in both husk-fed groups. Caecal contents accounted for $72 \%$ of the total caecal wet weight in the fibre-free group, $85 \%$ in all Plantago ovata preparations and $77 \%$ in the wheat-bran groups. In the colon, the contents contributed $50 \%$ of the total fresh weight in fibre-deficient rats, $61-69 \%$ in the 
PL. OVATA SEEDS AS FIBRE SUPPLEMENT

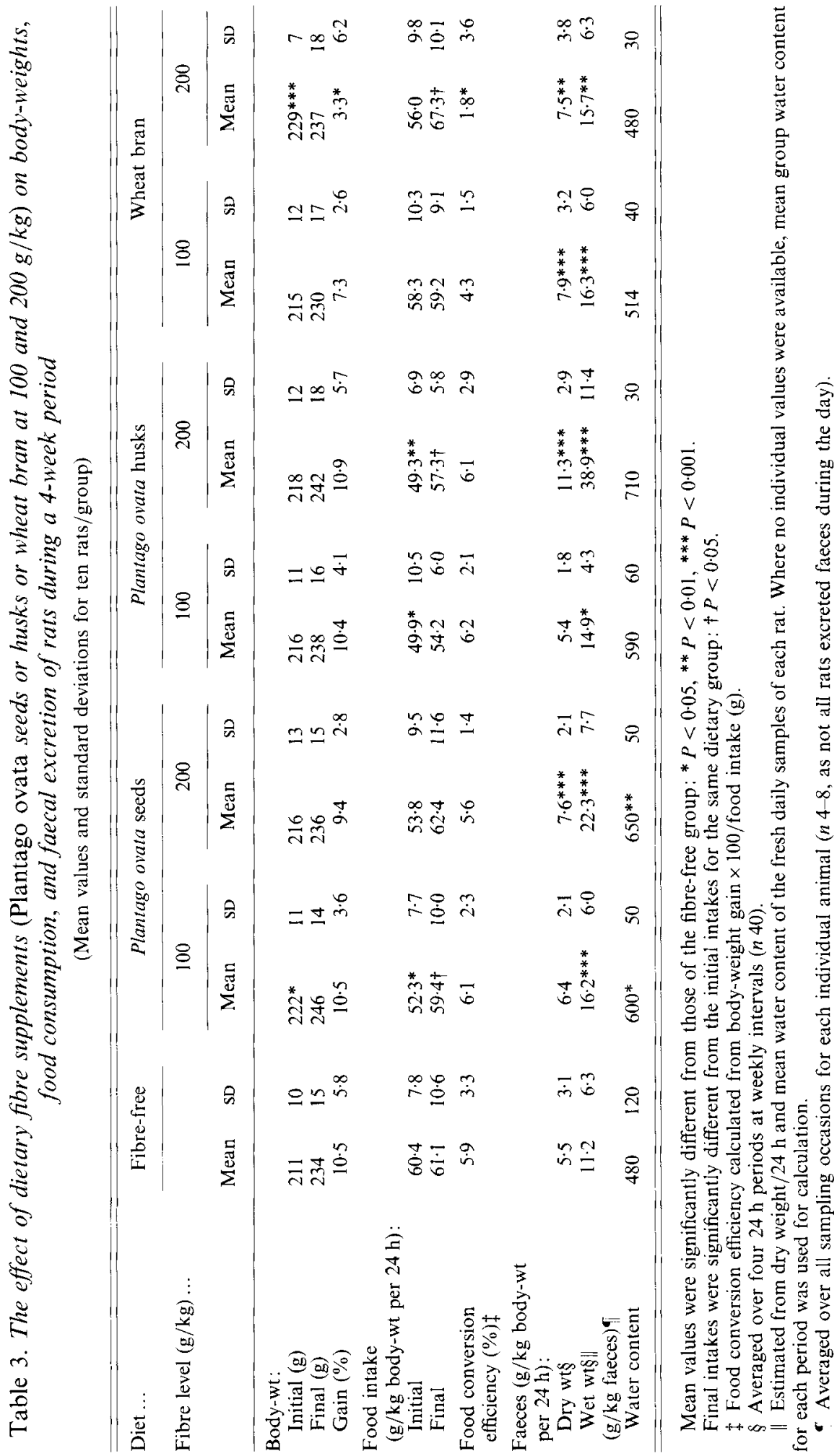




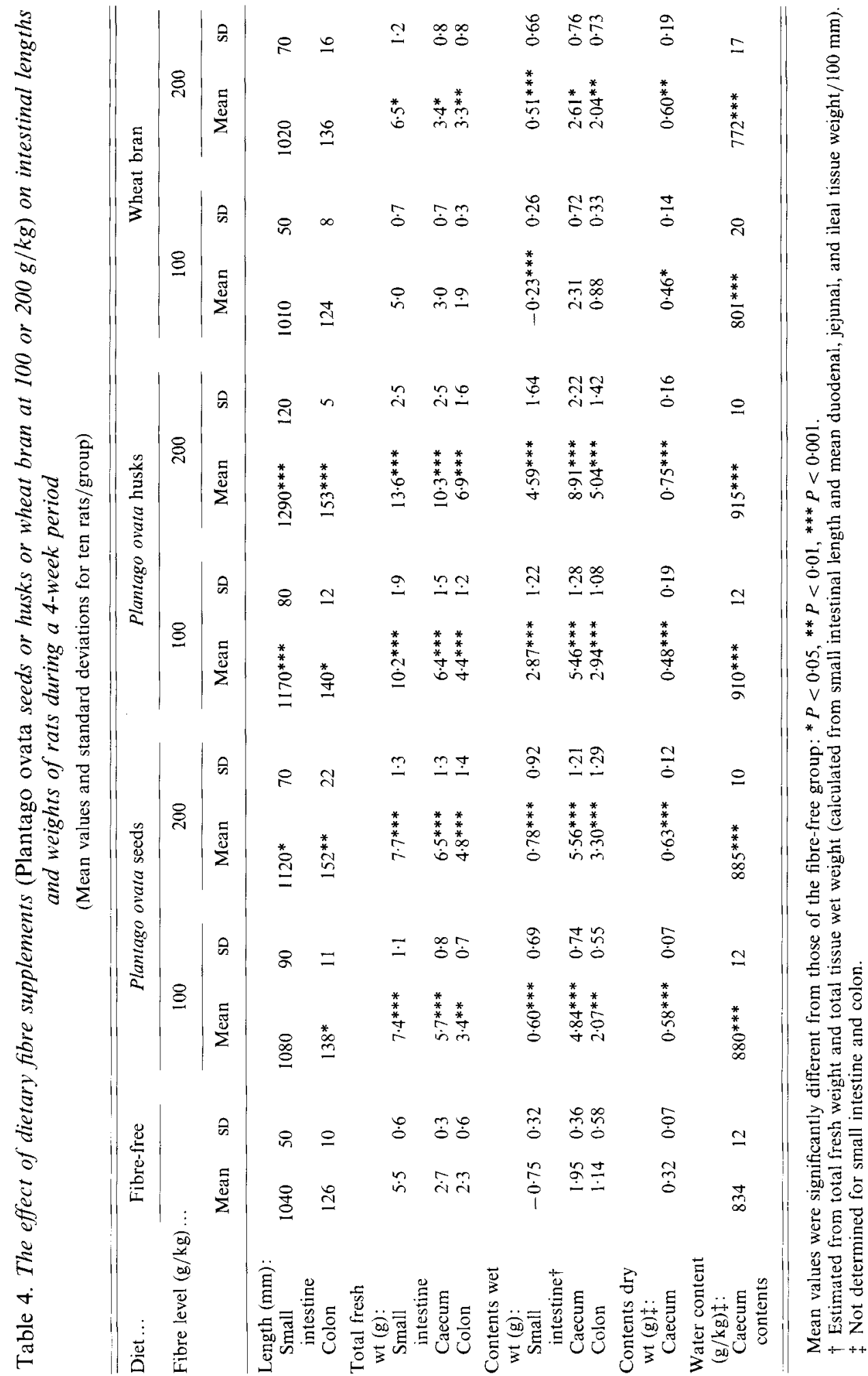


seed-containing diets, $67-73 \%$ in the husk-containing diets, and $46-62 \%$ in the wheat-bran diets. Water content of food residues, which was only measured in the caecum, was $83 \%$ in fibre-free rats and even less in the wheat-bran groups, and increased to 88 and $91 \%$ for diets containing Plantago ovata seeds and husks respectively.

Tissue weight (Table 5) per $100 \mathrm{~mm}$ length was not influenced in the upper small intestine by any of the dietary fibres but increased in the middle and lower parts of the small intestine and in the colon in the presence of the husks, especially at the high concentration. Plantago ovata seeds, 100 and $200 \mathrm{~g} / \mathrm{kg}$, and wheat bran, $200 \mathrm{~g} / \mathrm{kg}$, had a significant effect in the caecum only which was, however, moderate compared with that with the husks. Tissue water content in the caecum and colon rose highly significantly in both husk-fed groups and less in the $200 \mathrm{~g}$ seeds $/ \mathrm{kg}$ and wheat-bran groups.

\section{Bacteria-dependent variables in caecal contents and faeces}

As dietary fibres individually affect the intestinal contents in various respects (water binding, non-degradable residue, bacterial mass), dilution problems complicate comparisons between the different groups based on concentration values related to $\mathrm{g}$ wet weight, g dry weight, protein content etc. Therefore, absolute amounts, related to $24 \mathrm{~h}$ faecal output or whole caecal contents, are given in addition to concentrations expressed on a dry weight basis (Table 6). As an exception, the activity of $\beta$-glucuronidase, which was determined in a single fresh faecal pellet, was related to wet weight only. Standard deviations of the calculated absolute amounts in faeces were rather high, as total faecal excretion sometimes varied considerably within a group.

$D A P A$. The concentration in faeces significantly increased in the Plantago ovata seed diet compared with the fibre-free treatment, both the other fibre types had no effect. The total amount of DAPA in a $24 \mathrm{~h}$ faeces sample was doubled in the two seed-fed groups and in the $200 \mathrm{~g}$ husks $/ \mathrm{kg}$ group. Wheat bran showed only a trend towards a higher amount.

Protein. The concentration in faeces was similar to that of the fibre-free control in the seed-fed and wheat-bran-fed rats, but decreased in both husk-fed groups. A significant dilution by an increased faecal dry weight mass was obvious in the $200 \mathrm{~g}$ husk/kg group and less so in the $200 \mathrm{~g}$ seeds $/ \mathrm{kg}$ group and both wheat-bran groups, but not in the $100 \mathrm{~g}$ husks or seeds $/ \mathrm{kg}$ groups compared with the fibre-free control. In caecal contents, protein concentration was reduced by all fibre-rich diets except $200 \mathrm{~g}$ wheat bran $/ \mathrm{kg}$. There was no direct correlation between protein concentration and dilution by an increased caecal dry weight mass in the different groups, as the same dry weight increase coincided with a decrease in protein concentration in the $200 \mathrm{~g}$ seeds $/ \mathrm{kg}$ group and an increase in the $200 \mathrm{~g}$ wheat bran $/ \mathrm{kg}$ group. Total protein content in faeces clearly increased with Plantago ovata seeds and wheat bran and was affected in the husk-fed group only at the $200 \mathrm{~g} / \mathrm{kg}$ concentration. In total caecal contents, the results were the same, but the husks, in a high concentration, increased protein content also.

$\beta$-Glucuronidase. The activity, related to $\mathrm{g}$ wet weight, showed a time-dependent decrease over 4 weeks in the faeces of rats receiving 100 or $200 \mathrm{~g}$ Plantago ovata seeds $/ \mathrm{kg}$ and $100 \mathrm{~g}$ husks $/ \mathrm{kg}$, finally reaching $25 \%$ of the activity of the control group. Faecal water content did not change considerably within the groups during this time. The high-husk dietary group showed a sudden and pronounced reduction within the first $8 \mathrm{~d}$, falling to $10 \%$ of the activity of the fibre-free group, whereas wheat bran at a concentration of $100 \mathrm{~g} / \mathrm{kg}$ had no effect and at $200 \mathrm{~g} / \mathrm{kg}$ led to a $50 \%$ reduction. In caecal contents, $\beta$-glucuronidase activity decreased in both Plantago ovata preparations but not in the wheat bran group which may be partly explained by the changes in water content. Although dry weight had not been determined in the faecal pellets used for $\beta$-glucuronidase determinations, an attempt was made to calculate total faecal $\beta$-glucuronidase output on the basis of the $24 \mathrm{~h}$ dry matter and the mean water content of the fresh faeces of each rat (or, if not available, 


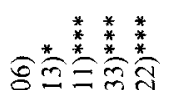

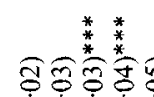

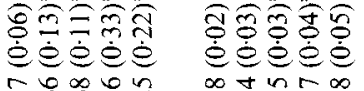

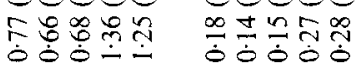

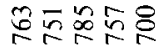

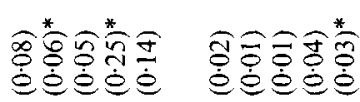

당영영

$\infty=\pi$ 我

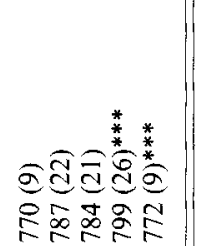

$*$
$*$
$*$
$\dot{0}$
$v$
2
2
$*$
$*$
$\dot{0}$ 
PL. OVATA SEEDS AS FIBRE SUPPLEMENT

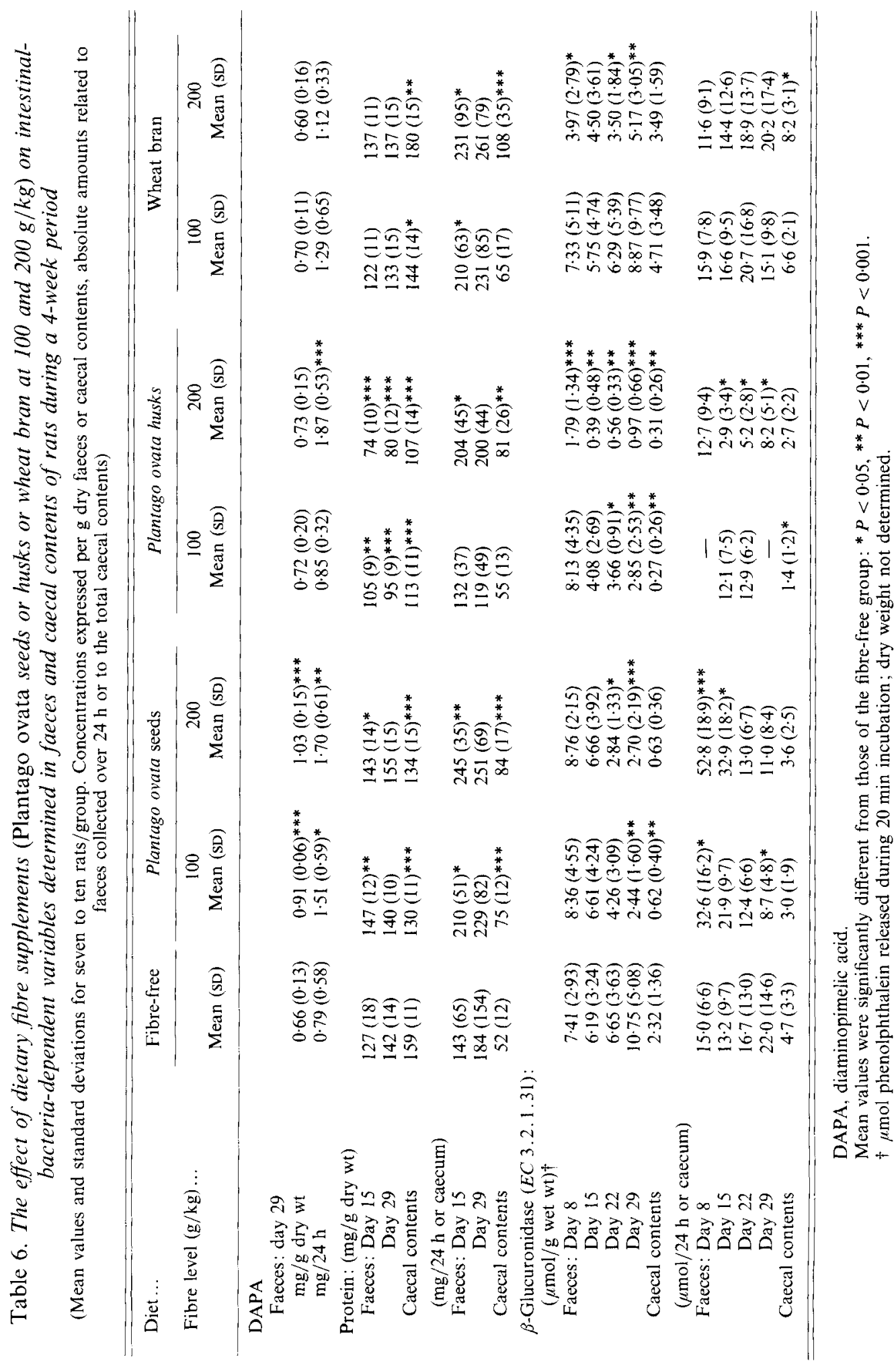


of the group) collected on the preceding day. An initial increase in total faecal $\beta$ glucuronidase activity was found for the seeds (indicating that the effect on enzyme inhibition was delayed compared with the increase in stool weight) followed by a decrease until the end of the experimental period. In parallel with the concentration findings, the decrease was more rapid in the high-husk dietary group. Wheat bran induced no change compared with the fibre-free control. In total caecal contents, differences in the $\beta$ glucuronidase activity between the groups were not as pronounced as in faeces except for a low activity in the $100 \mathrm{~g}$ husk/ $\mathrm{kg}$ group and a high activity in the $200 \mathrm{~g}$ wheat $\mathrm{bran} / \mathrm{kg}$ group.

\section{Fermentation and short-chain fatty acids (SCFA)}

Total amounts of acetate as a main product of bacterial fermentation showed a pronounced increase in caecal contents and faeces of rats fed with Plantago ovata seeds or husks but generally not in wheat-bran-fed rats (Table 7). There were no important differences between the two Plantago ovata preparations. The $\mathrm{pH}$ of the caecal contents did not correlate with acetate in that an increasing concentration of SCFA lowered $\mathrm{pH}$. Wheatbran-fed rats with the lowest acetate concentration had the most acid $\mathrm{pH}$ in the caecum.

\section{Total bile acids}

The concentration of the $3 \alpha$-hydroxy bile acids and their total amounts significantly increased in dried caecal contents and faeces of rats fed on either of the two Plantago ovata preparations (Table 7). The effect was more pronounced in the husk-fed group than in the seed-fed group. There was little change in wheat-bran-fed animals compared with the fibrefree group. On a wet weight basis (values not shown), the bile acid concentration in caecal contents did not significantly differ from that of the fibre-free controls in all treated groups with the exception of the $200 \mathrm{~g}$ seeds/ $\mathrm{kg}$ group which was elevated by $56 \%$.

\section{Mucosal enzymes in the small intestine}

Plantago ovata seeds produced a dose-dependent reduction in the activity of AP in the jejunum by 31 and $92 \%$, of sucrase by 16 and $30 \%$, of LAP by 3 and $53 \%$, and of $\alpha$ amylase by 53 and $26 \%$ respectively (Table 8 ). The other two dietary fibres depressed AP activity, already at a low concentration, by more than $90 \%$, sucrase activity by $7-21 \%$, LAP activity by $47-58 \%$ and amylase activity by $39-57 \%$.

In the ileum of the control rats, all enzyme activities were lower than in the jejunum, especially AP, sucrase, and $\alpha$-amylase. Changes in enzyme activities due to the fibreenriched diet were less dramatic than in the upper region. In contrast to the jejunum, AP activity was significantly increased 2-3-fold by the two Plantago ovata preparations and, to a lesser extent, by wheat bran. Sucrase activity was almost unaffected. LAP and $\alpha$-amylase activities were reduced by the diets containing seeds and husks and only $\alpha$-amylase was reduced, by $20 \%$, with wheat bran.

\section{DISCUSSION}

\section{Faecal bulking}

The effect of a dietary fibre on faecal bulking is mainly due to the presence of its indigestible residue, the water-binding capacity of this residue and on the bacterial mass which depends on the amount of fermentable substrate in the large intestine (Cummings, 1984). Plantago ovata husks, as a highly-soluble fibre, are digested to $70-90 \%$ by the large intestinal microflora (Prynne \& Southgate, 1979; Nyman \& Asp, 1985). Fibres with a high content of insoluble carbohydrates are more resistant. Wheat bran is broken down only to about $40 \%$ (Nyman \& Asp, 1982; Nyman et al. 1986). The degree of bacterial degradation of Plantago ovata seeds is not known, but based on its fibre composition it may be supposed 
PL. OVATA SEEDS AS FIBRE SUPPLEMENT

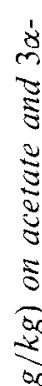

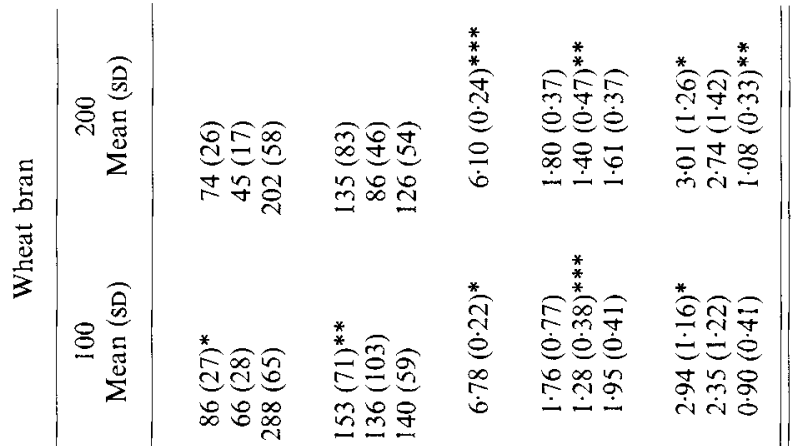

8

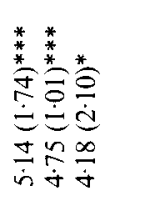

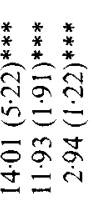

워ำ

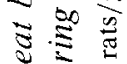

$\stackrel{2}{\Xi}$

亏

参家泀

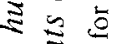

o

$\stackrel{5}{5}$

ชิ

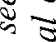

is

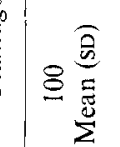

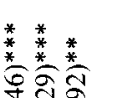

* * *

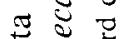

艺

8

$\stackrel{\Xi}{=}$

(1)

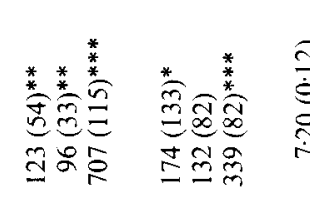

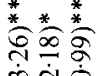

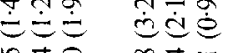

अंष्त

|

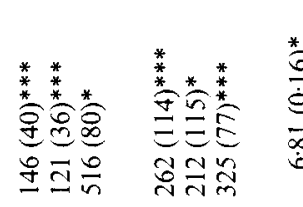

E $\frac{5}{3}$

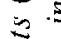

胥

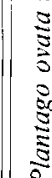

뉸

空客

ज

$\stackrel{3}{3}$

3

$\frac{\pi}{2}$

है

$\therefore$

$\frac{y}{0}$

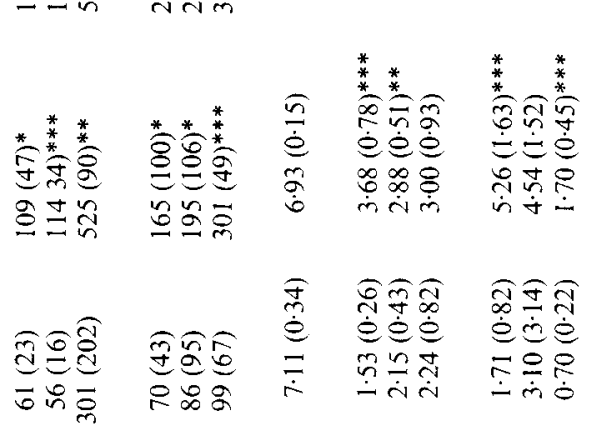

家

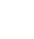

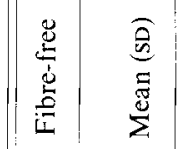

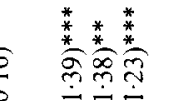

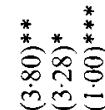

훙ํํ

윰

$\therefore \dot{\circ}$

$\overrightarrow{8}$
$\dot{0}$
$v$
2
$*$
$*$
$*$

*

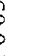




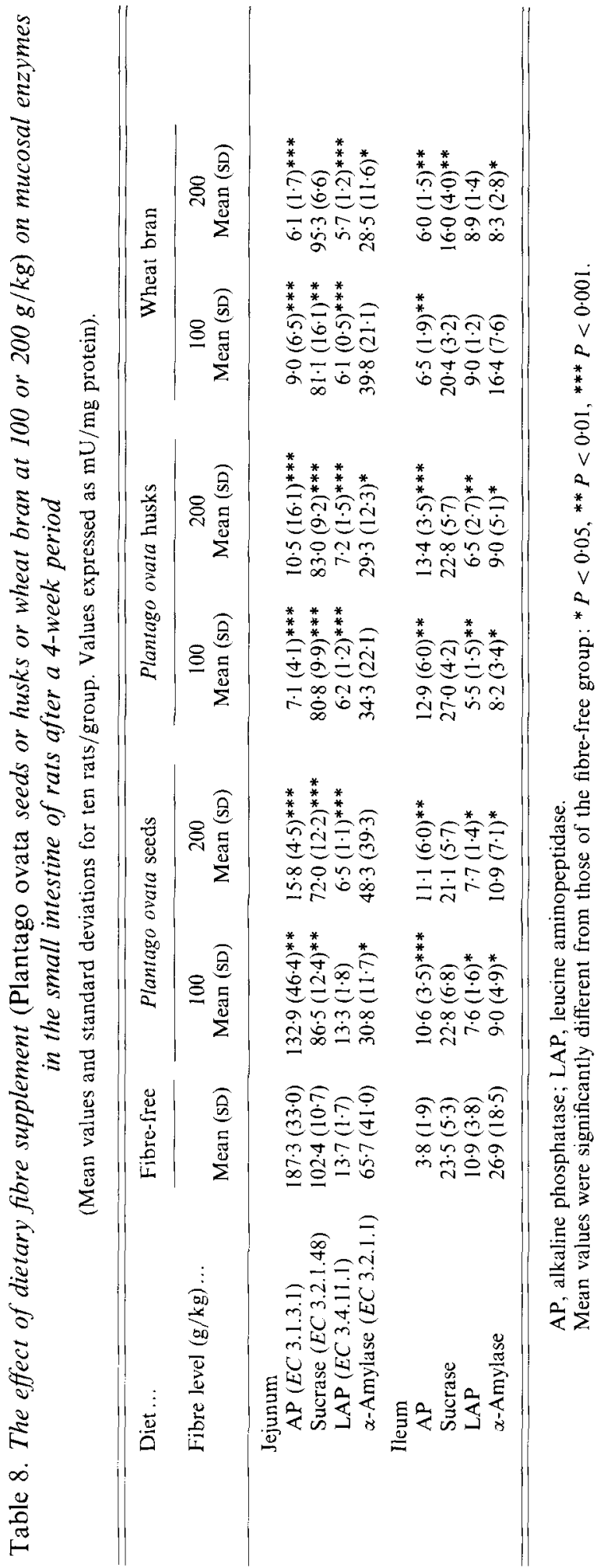


that its digestibility should be less than that of the husks and greater than that of wheat bran. The particle size of fibre has also been shown to be important for digestibility and stool weight (Brodribb \& Groves, 1978). Fine bran has a lower water-holding capacity, probably a higher digestibility and a weaker effect on stool weight than coarse bran. A comparison of the sieve analysis values from the present study with those of Brodribb \& Groves (1978) show that the bran used in the present study was of a coarse nature. The predominating particle size of Plantago ovata husks was smaller than wheat bran, and that of the seeds even smaller, but still above $0.5 \mathrm{~mm}$.

The increase in faecal wet weight in the $100 \mathrm{~g}$ fibre $/ \mathrm{kg}$ diets was similar for all fibres, but in the $200 \mathrm{~g}$ fibre $/ \mathrm{kg}$ diets pronounced differences were seen, following the order husks $>$ seeds $>$ wheat bran. Dose-dependencies were evident for both forms of Plantago fibre, but not for wheat bran. The increased faecal water content was mainly associated with the bulking effect of the husks, and also with that of the seeds, whereas in wheat-branfed rats faecal water content was in the range of the fibre-free controls. These findings relate to the water-holding capacity which is very high for husks, moderate for seeds and low for wheat bran (Leng-Peschlow 1990).

In relation to the increase in faecal dry weight, wheat bran was more effective than Plantago ovata seeds and husks except for the high-husk diet. On the basis of the predicted level of indigestible fibre residues, the effect of the high-husk diet is difficult to explain. A particularly high contribution of the biomass to faecal dry weight due to extensive fermentation and growth of bacteria in the large intestine is not indicated by the measured bacterial markers (DAPA, protein) in the $200 \mathrm{~g}$ Plantago ovata husk/kg group. Thus, it might be speculated that due to the large volume of the intestinal contents induced by the high-husk diet, transit of digesta in the colon is mostly accelerated in this group and, therefore, a greater proportion of fibre escaped digestion. It is well known that colon motility and propulsion of contents is influenced by the load of material (Bardon \& Fioramonti, 1983; Read, 1986) and that the retention time determines the degree of digestion of fibre components (Sakaguchi et al. 1987).

\section{2,6-Diaminopimelic acid}

This is a constituent of the bacterial cell wall and can be regarded as a marker of bacterial mass (Work \& Dewey, 1953; Hutton et al. 1971). With a standard diet, bacterial mass amounts to approximately $50 \%$ of dry faecal matter in humans (Stephen \& Cummings, 1980). In the present study, total faecal DAPA excretion and DAPA concentration in the faeces was highest with the diet containing Plantago ovata seeds and not significantly different from that of the fibre-free control with the wheat-bran diet. The latter confirms results of Walter et al. (1988). As increased fermentation favours the growth of bacterial mass, these results indicate a higher digestibility of the seeds compared with wheat bran. A high DAPA excretion was also expected for the diet containing husks, but this was only evident in the $200 \mathrm{~g} / \mathrm{kg}$ group due to the high output of faecal material and not because of an increase in DAPA concentration.

\section{Faecal protein excretion}

This may also be used as a marker of bacterial mass, although part of the protein may be of non-bacterial origin, e.g. sloughed intestinal cells or nutritional protein which escaped digestion. Daily faecal protein excretion was highest with the diets containing wheat bran and Plantago ovata seeds, while the fibre-free control and the husk-containing diet were similar to each other, which is partly in contrast to the DAPA results. In caecal contents, total protein was also highest with the wheat-bran diet, whereas there was a similar amount in both Plantago ovata preparations. Wheat bran contains significant amounts of protein (Nyman \& Asp, 1982) and there might be a good chance that protein which is included in 
a poorly-digestible fibre matrix is largely protected from enzymic degradation and absorption. Plantago ovata seeds also contain some protein, but husks are nearly proteinfree (D. A. T. Southgate, personal communication; J. B. Robertson and P. J. Van Soest, personal communication). As the particle size and, thereby the preserved fibre structure, plays a role in the properties of a dietary fibre and also in the accessibility to the fibre constituents (Mongeau \& Brassard, 1982), it is likely that protein from the finely-powdered Plantago ovata seeds may be more easily available than that from the coarse wheat bran. Thus, undegraded protein may contribute more to the caecal and faecal protein contents with the wheat-bran diet than with the diet containing Plantago ovata seeds and plays no role with the husk-containing diet.

\section{Short-chain fatty acids}

A third indicator of bacterial activity is SCFA. SCFA are the predominant products of bacterial fermentation in the large intestine and acetate comprises $50-60 \%$ of the total amount, the rest being mainly propionate and butyrate (Cummings \& Branch, 1986). In the present study, the SCFA analysis has been limited to acetate due to methodological reasons. The amount of acetate in the intestinal contents is the net result of microbial production and its disappearance by absorption. SCFA are rapidly absorbed from the hind-gut (Leng-Peschlow \& Marty, 1979; Rechkemmer et al. 1988). The absence of an increase in lumen SCFA does not necessarily imply no increase in production, as this is a question of the absorption rate and capacity. The levels of SCFA decrease along the large intestine (Mitchell et al. 1985) and it has been found that stool SCFA concentrations remain rather stable despite a variety of dietary or pathological conditions (McKay \& Eastwood, 1983; Vernia et al. 1984). In the present investigation, however, both Plantago ovata preparations increased acetate concentration in caecal contents as well as in faeces, whereas wheat bran did not. This effect is still more pronounced when values were expressed as total faecal excretion or related to total caecal contents. On this basis, wheat bran showed a tendency towards an increased SCFA output but results are generally not significantly different from those of the fibre-free control rats, confirming other findings (Walter et al. 1986). Caecal acetate concentration with the husk-containing diet was higher than that with the seed-containing diet, which may result from a higher fermentation but may also be the consequence of a delayed absorption due to a higher viscosity of the intestinal contents. Thus, the acetate results presented here suggest that wheat bran has a low digestibility and Plantago ovata preparations have a higher digestibility, but a differentiation between husks and seeds is not possible.

$$
p H
$$

A high SCFA concentration in the caecum is expected to correlate with a low $\mathrm{pH}$, but the converse was the case in our experiments. Rats fed with the high-wheat-bran diet had the lowest acetate concentration and by far the lowest $\mathrm{pH}$ in caecal contents; rats fed with the $100 \mathrm{~g}$ husks $/ \mathrm{kg}$ diet had the highest caecal acetate concentration and the highest $\mathrm{pH}$. As some dietary fibres induce a shift in the acetate, propionate and butyrate ratios (Topping et al. 1988), acetate alone may not be fully representative. There was, however, nearly no difference in the SCFA composition of cultured colonic contents from cellulose or 'psyllium'-husk-fed monkeys (Costa et al. 1989). In addition, the relationship between $\mathrm{pH}$ and total SCFA is far from being clear. Some authors have found the expected correlation (Demigné \& Rémésy, 1985), some authors' findings concur with the present results (Ruppin et al. 1980), and some do not observe any relationship at all (Argenzio \& Southworth, 1975). It is, however, a rather consistent finding that wheat bran lowers caecal pH (Jacobs \& Lupton, 1982) despite a low fermentation. Less than $1 \%$ of the SCFA are protonated 
at a neutral $\mathrm{pH}$, but more than half of them are absorbed in the undissociated, lipid-soluble form. As a proton donor, an electroneutral $\mathrm{Na}^{+}-\mathrm{H}^{+}$exchange and hydration of carbon dioxide within the lumen fluid with subsequent dissociation into proton and bicarbonate seems to be involved (Rechkemmer et al. 1988). The latter results in bicarbonate accumulation within the lumen and this may explain an increasing $\mathrm{pH}$ with increasing SCFA absorption.

\section{$\beta$-Glucuronidase}

This is an enzyme produced by a variety of bacterial strains in the large intestine (Gadelle et al. 1985). Its activity is strongly influenced by the diet, being high in a high-meat diet and usually lower in a high-fibre diet (Reddy et al. 1974; Goldin et al. 1978; Shiau \& Chang, 1983 ). In the present study, the faecal and caecal $\beta$-glucuronidase activity was pronouncedly decreased by Plantago ovata seeds and husks, and by wheat bran to a lesser extent (faeces) or not at all (caecal contents). Total excretion was also reduced by both Plantago ovata preparations, while wheat bran had no effect. The importance of $\beta$-glucuronidase activity is based on its function of deconjugating many endogenous and exogenous compounds. As glucuronidation is a major detoxification mechanism in the liver and also in the intestinal mucosa, a high $\beta$-glucuronidase activity in the large intestine will release significant amounts of toxic agents excreted with bile which may affect the large intestinal mucosa. In fact, an increase in $\beta$-glucuronidase activity accompanies an increased colo-rectal tumour incidence in experimental carcinogenesis studies (Bauer et al. 1979; Sun \& Li, 1988) which can be suppressed by a $\beta$-glucuronidase inhibitor (Takada et al. 1982). Plantago ovata husks have also been shown to possess anticarcinogenic properties in 1,2-dimethylhydrazine (DMH)-induced tumours in rats (Wilpart et al. 1987).

\section{Bile acids}

Conjugated bile acids are physiological substrates for $\beta$-glucuronidase in the large bowel, and bile flow is an important factor in modulating $\beta$-glucuronidase activity (Roberton et al. 1982; Head et al. 1988). It seems, however, unlikely that the Plantago ovata diets reduced $\beta$-glucuronidase activity by decreasing bile flow, as total bile acids in the caecum and also excretion in faeces is pronouncedly enhanced. Other possibilities are via a more direct effect on the composition or metabolic state of the microflora. Deconjugated primary bile acids are easily metabolized by the bacterial flora to the more toxic secondary ones (Morotomi et al. 1979; Hirano et al. 1981). The latter are known to increase mucosal permeability (Goerg et al. 1980), to stimulate mucosal proliferation (Craven et al. 1986) and to possess a tumour-promoting activity (Owen et al. 1987). By binding of bile acids and suppression of bacterial $\beta$-glucuronidase activity, the Plantago ovata fibres may decrease the toxicity and absorption of bile acids in the colon.

Increased bile acid excretion seems to be a main mechanism for the plasma cholesterolreducing effect of some fibres. A hypocholesterolaemic effect has been shown for the husks (Forman et al. 1968; Danielsson et al. 1979; Burton \& Manninen, 1982) and may be expected for the seeds, too, on the basis of the present results.

\section{Morphological changes}

There were no changes in the intestine with wheat bran in the present study, which confirms previous findings (Vahouny et al. 1985). In contrast, Plantago ovata husks caused a pronounced increase in small intestine and colon lengths, as well as tissue weights in the ileum, caecum and colon. Histologically, an increase in the mucosal thickness of the distal small intestine as well as an increase in villous height has been found with Plantago ovata husks (Sud et al. 1988). The seeds had almost no effect in the small intestine, but influenced 
colon length to a similar degree to that of the husks; tissue weight was unaffected except for the caecum. The swelling properties of the fibres in the intestine and, thereby, the volume of the contents seem to be important factors in influencing the bowel wall (Wyatt et al. 1988). Plantago ovata husks have the highest water-binding capacity and obviously swell early in the gastrointestinal tract, whereas bulking seems to be delayed in the seeds, being evident especially in the large intestine. Wheat bran with a low water-binding capacity causes only a weak bulking of intestinal contents.

Besides the influence of an increased bulk of contents, there are additional aspects in the large intestine which may be important for the enlargement and tissue hypertrophy. These derive from the metabolic effects of the SCFA produced from fermentable fibres. It is well known that SCFA stimulate mucosal proliferation and it has been suggested that the trophic action of the SCFA is necessary to maintain the normal epithelial cell proliferation in the intestine (Sakata, 1986, 1987, 1988). In vitro studies with butyrate demonstrate an induction of cell differentiation (Muller et al. 1986), stimulation of the DNA repair capacity (Nishigori \& Takebe, 1987), and growth delay of malignant cells (Kim et al. 1980). Thus, SCFA produced by Plantago ovata seeds or husks may contribute to the structural and functional integrity of the mucosa. Induction of mucosal cell proliferation by dietary fibres as compared with long-term fibre-free diets appears as a process of normalization and not as a pathological finding.

\section{Mucosal enzyme activities}

Finally, in the present study, Plantago ovata seeds and husks as well as wheat bran influenced mucosal enzyme activities in the proximal and the distal small intestine. There was a pronounced inhibition of AP, LAP, sucrase and $\alpha$-amylase in the jejunum with all three dietary fibres to a similar extent. In the ileum, enzyme activities in the control group were usually lower and the effects of the fibres more heterogeneous. Enzyme studies on the proximal small intestine mucosa of rats fed other fibres show a wide spectrum of influences including stimulation and inhibition of activities (Farness \& Schneeman, 1982; Johnson et al. 1984; Brown et al. 1979; Johnson \& Gee, 1986). The causes of the influence of dietary fibres on mucosal enzyme activities are not well known. A direct interaction due to binding or the presence of enzyme inhibitors, especially in natural fibres, as has been shown in in vitro studies (Dunaif \& Schneeman, 1981; Hansen, 1987), is unlikely. As substrate availability is important, one may suppose that dilution of the diet by the fibre may determine enzyme activities, but our experiments demonstrate that the degree of inhibition was different for the various enzymes and generally independent of dilution by fibres. In addition, their physicochemical properties, resulting in different viscosities of the contents, do not seem to play an essential role in the observed effects. It has been suggested that reduction in villous enzyme activities may be due to an increase in cell proliferation and cell-turnover induced by some fibres (Brown et al. 1979; Johnson \& Gee, 1986), but proliferation effects, if present, generally are more evident in the distal than in the proximal part of the small intestine. In addition, stimulation of certain enzymes was observed simultaneously with the inhibition of others (Johnson \& Gee, 1986; present results) which speaks against a general effect of increased cell turnover. Finally, it has been shown that fibres, e.g. Plantago ovata husks and seeds, also stimulate enzyme activities in vitro (LengPeschlow, 1990). The physiological significance for digestion of the alterations in mucosal or lumen enzyme activities by dietary fibres still remains unclear.

According to an expert panel, the fibre composition of a well-balanced diet consisting of a wide variety of foods is $700-750 \mathrm{~g}$ insoluble fibres and $250-300 \mathrm{~g}$ soluble fibres $/ \mathrm{kg}$ (Pilch, 1987). It is not known whether this is an ideal ratio, but it might be reasonable to assume that supplementation of fibre-deficient diets with concentrated fibres should be oriented to 
a healthy natural diet, if there are no special requirements. Regarding the fibre composition, Plantago ovata seeds may, therefore, be a suitable physiologically-acting fibre supplement. The present results indicate that the seeds are a partly-digestible dietary fibre which acts mainly in the large intestine and increases stool volume by a mixture of indigestible residue, water-binding and increase in bacterial mass. Metabolic and mucosa-protective effects based on augmented bile acid excretion, reduced $\beta$-glucuronidase activity and stimulation of SCFA production are probable. A high bulking in the upper gut, which is characteristic for Plantago ovata husks, is avoided.

The author would like to thank Dr Rabe, Bundesforschungsanstalt für Getreide- und Kartoffelverarbeitung, Detmold, Germany, for the fibre analyses. This paper is dedicated to Mrs Hanna Madaus on the occasion of her 95th birthday.

\section{REFERENCES}

Argenzio, R. A. \& Southworth, M. (1975). Sites of organic acid production and absorption in gastrointestinal tract of the pig. American Journal of Physiology 228, 454-460.

Bardon, T. \& Fioramonti, J. (1983). Nature of the effects of bran on digestive transit time in pigs. British Journal of Nutrition 50, 685-690.

Bauer, H. G., Asp, N.-G., Öste, R., Dahlquist, A. \& Fredlund, P. E. (1979). Effect of dietary fiber on the induction of colorectal tumours and fecal $\beta$-glucuronidase activity in the rat. Cancer Research 39, 3752-3756.

Brodribb, A. J. M. \& Groves, C. (1978). Effect of bran particle size on stool weight. Gut 19, 60-63.

Brown, R. C., Kelleher, J. \& Losowsky, M. S. (1979). The effect of pectin on the structure and function of the rat small intestine. British Journal of Nutrition 42, 357-365.

Burton, R. \& Manninen, V. (1982). Influence of a psyllium-based fibre preparation on faecal and serum parameters. Acta Medica Scandinavica Suppl. 668, 91-94.

Costa, M. A., Mehta, T. \& Males, J. R. (1989). Effects of dietary cellulose and psyllium husk on monkey colonic microbial metabolism in continuous culture. Journal of Nutrition 119, 979-985.

Craven, P. A., Pfanstiel, J., Saito, R. \& DeRuberties, F. R. (1986). Relationship between loss of rat colonic surface epithelium induced by deoxycholate and initiation of the subsequent proliferative response. Cancer Research $\mathbf{4 6}$, $5754-5759$.

Cummings, J. H. (1984). Constipation, dietary fiber and control of large bowel function. Postgraduate Medical Journal 60, 811-819.

Cummings, J. H. \& Branch, W. J. (1986). Fermentation and the production of short-chain fatty acids in the human large intestine. In Dietary Fiber, Basic and Clinical Aspects, pp. 131-148 [G. V. Vahouny and D. Kritchevsky, editors]. New York and London: Plenum Press.

Czerkawski, J. W. (1974). Methods for determining 2,6-diaminopimelic acid and 2-aminoethylphosphonic acid in gut contents. Journal of the Science of Food and Agriculture 25, 45-55.

Dahlquist, A. (1970). Assay of intestinal disaccharidases. Enzymologia Biologica Clinica 11, 52-56.

Danielsson, A., Ek, B., Nyhlin, H. \& Steen, L. (1979). Effect of long term treatment with hydrophilic colloid on serum lipids. Acta Hepato-Gastroenterology 26, 148-153.

Demigné, C. \& Rémésy, C. (1985). Stimulation of absorption of volatile fatty acids and minerals in the cecum of rats adapted to a very high fiber diet. Journal of Nutrition 115, 53-60.

Dreher, M. L. (1987). Dietary fiber and its link to disease. In Handbook of Dietary Fiber. An Applied Approach, pp. 281-322 [M. L. Dreher, editor]. New York and Basel: Marcel Dekker, Inc.

Dunaif, G. \& Schneeman, B. O. (1981). The effect of dietary fiber on human pancreatic enzyme activity in vitro. American Journal of Clinical Nutrition 34, $1034-1035$.

Eastwood, M. A., Robertson, J. A., Brydon, W. G. \& MacDonald, D. (1983). Measurement of water-holding properties of fibre and their faecal bulking ability in man. British Journal of Nutrition 50, 539-547.

Englyst, H. M., Bingham, S. A., Runswick, S. A., Collinson, E. \& Cummings, J. H. (1989). Dietary fibre (nonstarch polysaccharides) in cereal products. Journal of Human Nutrition and Dietetics 2, 253-271.

Evrard, E. \& Janssen, J. (1968). Gas -liquid chromatograph determination of human fecal bile acids. Journal of Lipid Research 9, 226-236.

Farness, P. L. \& Schneeman, B. O. (1982). Effects of dietary cellulose, pectin and oat bran on the small intestine in the rat. Journal of Nutrition 112, 1315-1319.

Forman, D. T., Garvin, J. E., Forestner, J. E. \& Taylor, C. B. (1968). Increased excretion of fecal bile acids by an oral hydrophilic colloid. Proceedings of the Society for Experimental Biology and Medicine 127, 1060-1063.

Gadelle, D., Raibaud, P. \& Sacquet, E. (1985). $\beta$-Glucuronidase activities of intestinal bacteria determined both in vitro and in vivo in gnotobiotic rats. Applied and Environmental Microbiology 49, 682-685. 
Goerg, K. J., Gross, M., Ncll, G., Rummel, W. \& Schulz, L. (1980). Comparative study of the effect of cholera toxin and sodium deoxycholate on the paracellular permeability and on net fluid and electrolyte transfer in the rat colon. Naunyn-Schmiedeberg's Archives of Pharmacology 312, 91-97.

Goldin, B. R., Dwyer, J., Gorbach, S. L., Gordon, W. \& Swenson, L. (1978). Influence of diet and age on fecal bacterial enzymes. American Journal of Clinical Nutrition 31, 136-140.

Hansen, W. E. (1987). Effect of dietary fiber on pancreatic lipase activity in vitro. Pancreas 2, $195-198$.

Head, M. R., Fukumoto, H. E. \& Chang, G. W. (1988). Pancreatobiliary and biliary control of fecal $\beta$ glucuronidase activity in the rat. Cancer Letters 39, 339-344.

Heckers, H. \& Zielinsky, D. (1984). Fecal composition and colonic function due to dietary variables. Practical Gastroenterology Special Issue on the Symposium on Intestinal Motility (Lisbon), pp. 24-39.

Hirano, S., Masuda, N., Oda, H. \& Imamura, T. (1981). Transformation of bile acids by mixed microbial cultures from human feces and bile acid transforming activities of isolated bacterial strains. Microbiology and Immunology 25, 271-282.

Hutton, K., Bailey, F. J. \& Annison, E. F. (1971). Measurement of the bacterial nitrogen entering the duodenum of the ruminant using diaminopimelic acid as a marker. British Journal of Nutrition 25, 165-173.

Jacobs, L. R. \& Lupton, J. R. (1982). Dietary wheat bran lowers colonic pH in rats. Journal of Nutrition 112 , $592-594$.

Johnson, I. T. \& Gee, J. M. (1986). Gastrointestinal adaptation in response to soluble non-available polysaccharides in the rat. British Journal of Nutrition 55, 497-505.

Johnson, I. T., Gee, J. M. \& Mahoney, R. R. (1984). Effect of dietary supplements of guar gum and cellulose on intestinal proliferation, enzyme levels and sugar transport in the rat. British Journal of Nutrition 52, 477-487.

Kim, Y. S., Tsao, D., Siddiqui, B., Whitehead, J. S., Arnstein, P., Bennett, J. \& Hicks, J. (1980). Effects of sodium butyrate and dimethylsulfoxide on biochemical properties of human colon cancer cells. Cancer 45, 1185-1192.

Leng-Peschlow, E. (1990). Interference of dietary fibres with gastrointestinal enzymes in vitro. Digestion 44, $200-210$.

Leng-Peschlow, E. \& Marty, J. (1979). Absorption of water, electrolytes and volatile fatty acids in the rabbit caecal pouch. Journal of Comparative Physiology 133, 205-210.

Ligny, G. (1988). Therapie des Colon irritabile. (Therapy of the irritable bowel syndrome.) Therapeuticon 7 , $449-453$.

McKay, L. F. \& Eastwood, M. A. (1983). The influence of dietary fibre on caecal metabolism in the rat. British Journal of Nutrition 50, 679-684.

Marlett, J. A., Ulysses, B., Li, K. \& Bass, P. (1987). Comparative laxation of psyllium with and without senna in an ambulatory constipated population. American Journal of Gastroenterology 82, 333-337.

Mitchell, B. L., Lawson, M. J., Davies, M., Grant, A. K., Roediger, W. E. W., Illman, R. J. \& Topping, D. L. (1985). Volatile fatty acids in the human intestine: Studies in surgical patients. Nutrition Research 5, $1089-1092$.

Mongeau, R. \& Brassard, R. (1982). Insoluble dietary fiber from breakfast cereals and brans: bile salt binding and water-holding capacity in relation to particle size. Cereal Chemistry 59, 413-417.

Morotomi, M., Kawai, Y. \& Mutai, M. (1979). Intestinal microflora and bile acids. In vitro cholic acid transformation by mixed fecal culture of rats. Microbiology and Immunology 23, 839-847.

Muller, D. E., Laeng, H. \& Schindler, R. (1986). Butyrate-induced cell differentiation of cell-cycle mutants and 'wild-type' mastocytoma cells: Histamine, 5-hydroxytryptamine and metachromatic granules as independently regulated differentiation markers. Differentiation 32, 82-88.

Nishigori, Ch. \& Takebe, H. (1987). Sodium butyrate stimulates cellular recovery from UV damage in xeroderma pigmentosum cells belonging to complementation group F. Japanese Journul of Cancer Research 78, 932936.

Nyman, M. \& Asp, N.-G. (1982). Fermentation of dietary fiber components in the rat intestinal tract. British Journal of Nutrition 47, 357-366.

Nyman, M. \& Asp, N.-G. (1985). Bulk laxatives: Their dietary fibre composition, degradation, and faecal bulking capacity in the rat. Scandinavian Journal of Gastroenterology 20, 887895.

Nyman, M., Asp, N.-G., Cummings, J. \& Wiggins, H. (1986). Fermentation of dietary fibre in the intestinal tract: Comparison between man and rat. British Journal of Nutrition 55, 487-496.

Owen, R. W., Dodo, M., Thompson, M. H. \& Hill, M. J. (1987). Faecal steroids and colorectal cancer. Nutrition and Cancer 9, 73-80.

Pilch, S. M. (1987). Recommendations for fiber intake in the United States. In Physiological Effects and Health Consequences of Dietary Fiber (FDA-Report), pp. 159-163 [M. Pilch, editor]. Bethesda: Life Sciences Research Office, Federation of American Society for Experimental Biology.

Prosky, L., Asp, N. G., Furda, J., De Vries, J. W., Schweizer, T. F. \& Harland, B. F. (1985). Determination of total dietary fiber in foods and food products: collaborative study. Journal of the Association of Official Analytical Chemists 68, 677-679.

Prynne, C. J. \& Southgate, D. A. T. (1979). The effects of a supplement of dietary fibre on faecal excretion by human subjects. British Journal of Nutrition 41, 495-503.

Rabe, E., Seibel, W., Suckow, P. \& Meuser, F. (1988). Vergleichende Bestimmungen von unlöslichen, löslichen und Gesamtballaststoffen in Getreideerzeugnissen. (Comparative analyses of insoluble, soluble and total dietary fibre in cereals.) Getreide, Meht und Brot 42, 297.305. 
Read, N. W. (1986). Dietary fiber and bowel transit. In Dietary Fiber, Basic and Clinical Aspects, pp. 81-100 [G. V. Vahouny and D. Kritchevsky, editors]. New York and London: Plenum Press.

Rechkemmer, G., Rönnau, K. \& von Engelhardt, W. (1988). Fermentation of polysaccharides and absorption of short chain fatty acids in the mammalian hindgut. Comparative Biochemistry and Physiology 90A, 563-568.

Reddy, B. S., Weisburger, J. H. \& Wynder, E. L. (1974). Fecal bacterial $\beta$-glucuronidase : Control by diet. Science $183,416.417$.

Roberton, A. M., Lee, S. P., Kindop, R., Stanley, R. A., Thomsen, L. \& Tasman-Jones, C. (1982). Biliary control of $\beta$-glucuronidase activity in the luminal contents of the rat ileum, caecum, and rectum. Cancer Research $\mathbf{4 2}$, 5165-5166.

Ruppin, H., Bar-Meir, S., Soergel, K. H., Wood, C. M. \& Schmitt, M. G. (1980). Absorption of short-chain fatty acids by the colon. Gastroenterology 78, 1500-1507

Sakaguchi, E., Itoh, H., Uchida, S. \& Horigome, T. (1987). Comparison of fibre digestion and digesta retention time between rabbits, guinea-pigs, rats and hamsters. British Journal of Nutrition 58, 149-158.

Sakata, T. (1986). Effects of indigestible dietary bulk and short-chain fatty acids on the tissue weight and epithelial cell proliferation rate of the digestive tract in rats. Journal of Nutrition Science and Vitaminology 32, 355-362.

Sakata, T. (1987). Stimulatory effect of short-chain fatty acids on epithelial cell proliferation in the rat intestine: a possible explanation for trophic effects of fermentable fibre, gut microbes and luminal trophic factors. British Journat of Nutrition 58, 95-103.

Sakata, T. (1988). Depression of intestinal epithelial cell production rate by hindgut bypass in rats. Scandinavian Journat of Gastroenterology 23, $1200-1202$.

Shiau, S.-Y. \& Chang, G. W. (1983). Effects of dietary fiber on fecal mucinase and $\beta$-glucuronidase activity in rats. Journal of Nutrition 113, 138-144.

Sölter, H. \& Lorenz, D. (1983). Summary of clinical results with prodiem plain, a bowel-regulating agent. Today's Therapeutic Trends 1, 45-59.

Sosulski, F. W. \& Cadden, A. M. (1982). Composition and physiological properties of several sources of dietary fiber, Journal of Food Science 47, 1472-1477.

Stephen, A. M. \& Cummings, J. H. (1980). The microbial contribution to human faecal mass. Journal of Medical Microbiology 13, 45-56.

Stevens, J., Van Soest, P. J., Robertson, J. B. \& Levitsky, D. A. (1988). Comparison of the effects of psyllium and wheat bran on gastrointestinal transit time and stool characteristics. Journat of the American Dietetic Association 88, 323-326.

Struthers, B. J. (1986). Warning: Feeding animals hydrophilic fiber sources in dry diets. Journal of Nutrition 116 , 47. 49.

Sud, S., Mahapatra, S. C., Biljani, R. L. \& Nayar, U. (1988). Effect of cellulose and ispaghula husk on small intestinal structure of young rats and hamsters. Indian Journal of Medical Research 87, 631-636.

Sun, Y. \& Li, Y. (1988). Induction of beta-glucuronidase activity during dimethylhydrazine carcinogenesis and additive effects of cholic acids and indole. Cancer Letters 39, 69-.76.

Takada, H., Hirooka, T., Hiramatsu, Y. \& Yamamoto, M. (1982). Effect of $\beta$-glucuronidase inhibitor on azoxymethane-induced colonic carcinogenesis in rats. Cancer Research 42, 331-334.

Topping, D. L., Mock, S., Trimble, R. P., Storer, G. B. \& Illman, R. J. (1988). Effects of varying the content and proportions of gum arabic and cellulose on caecal volatile fatty acid concentrations in the rat. Nutrition Research 8, 1013-1020

Vahouny, G. V., Le, T., Ifrim, I., Satchithanandam, S. \& Cassidy, M. M. (1985). Stimulation of intestinal cytokinetics and mucin turnover in rats fed wheat bran or cellulose. American Journal of Clinical Nutrition $\mathbf{4 1}$, 895900

Van Soest, P. J. (1984). Some physical characteristics of dietary fibres and their influence on the microbial ecology of the human colon. Proceedings of the Nutrition Society 43, 25-33.

Vernia, P., Breuer, R. I., Gnaedinger, A., Latella, G. \& Santoro, M. L. (1984). Composition of fecal water. Comparison of 'in vitro' dialysis with ultrafiltration. Gastroenterology 86, 1557-1561.

Walter, D. J., Eastwood, M. A. \& Brydon, W. G. (1986). An experimental design to study colonic fibre fermentation in the rat: the duration of feeding. British Journal of Nutrition 55, 465479.

Walter, D. J., Eastwood, M. A. \& Brydon, W. G. (1988). Fermentation of wheat bran and gum arabic in rats fed on elemental diet. British Journal of Nutrition 60, 225-232.

Wilpart, M., Mainguet, P. \& Roberfroid, M. (1987). Intestinal carcinogenesis and dietary fibres. Influence of cellulose or fybogel as constituent of low and high fat diets given chronically after the period of exposure to dimethylhydrazine. Scandinavian Journal of Gastroenterology 22, Suppl. 129, 285.

Work, E. \& Dewey, D. L. (1953). The distribution of $\alpha, \epsilon$-diaminopimelic acid among various micro-organisms. Journal of General Microbiology 9, 394-409.

Wyatt, G. M., Horn, N., Gee, J. M.\& Johnson, I. T. (1988). Intestinal microflora and gastrointestinal adaptation in the rat in response to non-digestible dietary polysaccharides. British Journal of Nutrition 60, 197-207. 